\title{
An Evaluation of Aquifer Characteristics of the Idemili River Catchment Area of Southeast, Nigeria
}

\author{
Ejiagwa, O. N., Nfor, B. N.*, Okpoko, E. I. and Anene, C.Z. \\ Department of Geology, \\ Chukwuemeka Odumegwu Ojukwu, University, \\ Anambra State, Nigeria \\ *Corresponding author's e-mail: nforbng@yahoo.com; Phone no.: +2348034737791
}

\begin{abstract}
Hydrogeologic studies were carried out in the Idemili River Catchment area of southeast Nigeria in order to determine its aquifer characteristics. The geologic formations underlying the study area are the Ogwashi Asaba Formation and the Nanka Sands. Pumping test were carried out for $72 \mathrm{hrs}$ on each borehole and the following data were obtained, borehole depth, static water level, dynamic water level, drawdown and borehole yield. The data were then used to compute, Transmissivity, hydraulic conductivity and specific capacity. At Akaboukwu, Uruagu, Nnewi where the Ogwashi Asaba Formation was intercepted. The depth of borehole drilled was 137 meters, static water level and dynamic water level recorded are 103 meters and 104.2 meters respectively and the drawdown was 1.21 meters. Computation made for hydraulic head, transmissivity, hydraulic conductivity, and specific yield were 29 meters, $65.62 \mathrm{~m}^{2} /$ day $2.262 \mathrm{~m} / \mathrm{s}$ and $4.394 \mathrm{~m}^{2} / \mathrm{hr}$. respectively. The depth of borehole in the Nanka Sands ranged from 134 meters in Mbanagu, Otolo Nnewi, through 186 meters at Nkolofia, Awka Etiti to as high as 237 meters at Eziumuru, Nnobi. Static water level ranged from 40.84 meters at Ndimgbu, Otolo, Nnewi through 97.07 meters at Ochannachi, Nnobi, to 143 meters at Awkaetiti. Drawdown values ranged from 0.24 meters at Umuezeani, Nnobi through 1.19 meters at Ndimgbu, Nnewi to 3.2 meters at Eziumuru, Nnobi. Borehole yield values of $62.53 \mathrm{~m}^{3} /$ day at Umunemelum, Nnobi through $119.96 \mathrm{~m}^{3} /$ day at Nkolofia, Awkaetiti, to $233.80 \mathrm{~m}^{3} /$ day at Ndimgbu, Nnewi were obtained. Computation made for hydraulic head ranged from 50 meters at Eziumuru, Nnobi through 61.22 meters at Awkaetiti to 94 meters at Ndimgbu, Nnewi. Transmissivity values ranged from $24.42 \mathrm{~m}^{2} /$ day at Umuobi, Nnobi through $61.70 \mathrm{~m}^{2} /$ day at Awkaetiti to $121.87 \mathrm{~m}^{2} / \mathrm{day}$ at Ndimgbu, Nnewi. Hydraulic conductivity values ranged from $0.411 \mathrm{~m} / \mathrm{s}$ at Umuobi, Nnobi through $3.937 \mathrm{~m} / \mathrm{s}$ at Nkolofia, Awkaetiti to $4.479 \mathrm{~m} / \mathrm{s}$ at Umuhai, Nnobi. Specific capacity values ranged from $1.496 \mathrm{~m}^{2} / \mathrm{hr}$ at Eziumuru, Nnobi through $8.864 \mathrm{~m}^{2} / \mathrm{hr}$ at Umudim Nnewi to $20.14 \mathrm{~m}^{2} / \mathrm{hr}$ at Awkaetiti. The recovery test showed that the time for the borehole to fully recover ranged from 3 minutes at Umudim Nnewi through 9 minutes at Umuhai, Nnobi to 15 minutes at Akaboukwu, Uruagu, Nnewi. These results if properly harnessed indicate that aquifers would be viable for groundwater exploitation in order to meet the daily water needs of an ever growing population.
\end{abstract}

Original Research Article

Received: $18^{\text {th }}$ Feb., 2018

Accepted: 07 ${ }^{\text {th }}$ Mar., 2018

Published: $14^{\text {th }}$ Mar., 2018

Keywords:

Pumping test

Recovery test

Groundwater

Static water level,

Transmissivity<smiles>C1CC2CCC1C2</smiles>

\section{INTRODUCTION}

$\mathrm{T}$ he study area (Idemili and environs) lies within latitudes $6^{\circ} 00 \mathrm{~N}$ and $6^{\circ} 10^{1} \mathrm{~N}$ and longitude $6^{\circ} 50^{1} \mathrm{E}$ and $7^{\circ} 00 \mathrm{E}$ and falls within the Anambra River Basin of Nigeria (Ofodile, 2002), with an area extent of approximately $351.56 \mathrm{~km}^{2}$. The major towns in the study area include Nnewi, Nnobi, Umuoji, Uke and Ojoto. It is accessible via AwkaNnewi and Onitsha-Nnewi asphalt roads. The population of the area is dense about 206,000 (NPC, 2006; Mac-millan, 2006; Oformata, 2002). The moisture laden southwest monsoon winds that comes from the Atlantic Ocean causes much rainfall in the area during the raining season resulting in an average rainfall of $1850 \mathrm{~mm} /$ year (Ileoje, 1985). Precipitation in the area recharge the aquifers in the catchment area. 


\section{Brief Geology and Hydrogeology of the Area}

The study area is underlain by two main Formations; the Eocene Nanka Sands and the Quaternary Ogwashi-Asaba Formation. (Nwajide, 2013; Reyment, 1965). The Nanka Sands underlies, Nnobi, Ojoto and some parts of Nnewi. In the study area it is a sequence of poorly consolidated, poorly sorted, friable, medium to coarse sands of Eocene age. The Formation contains thin band of claystone, siltstone and shale. The units have good porosity and permeability. The sandstone unit is aquiferous (Nwajide, 1979). Overlying the Nanka Sands is the Ogwashi-Asaba Formation. This consists of altercation of lignites and clays. The formation is aquiferous with good porosity and permeability. Fig. 1 shows geologic map of the study area.

The aquifers in the area range in depth from $134 \mathrm{~m}$ to $237 \mathrm{~m}$. Water levels occur at shallow depths in the plains and valley courses while the water levels occur at greater depths in the highland areas (Okpoko, 2017). Groundwater recharge in the study area is by infiltration from rainfall and surface runoff.

The cost of exploitation of deep aquifer is high amongst the inhabitants in the area with the attendant risk of drilling abortive boreholes because most times professionals are not involved during exploitation.

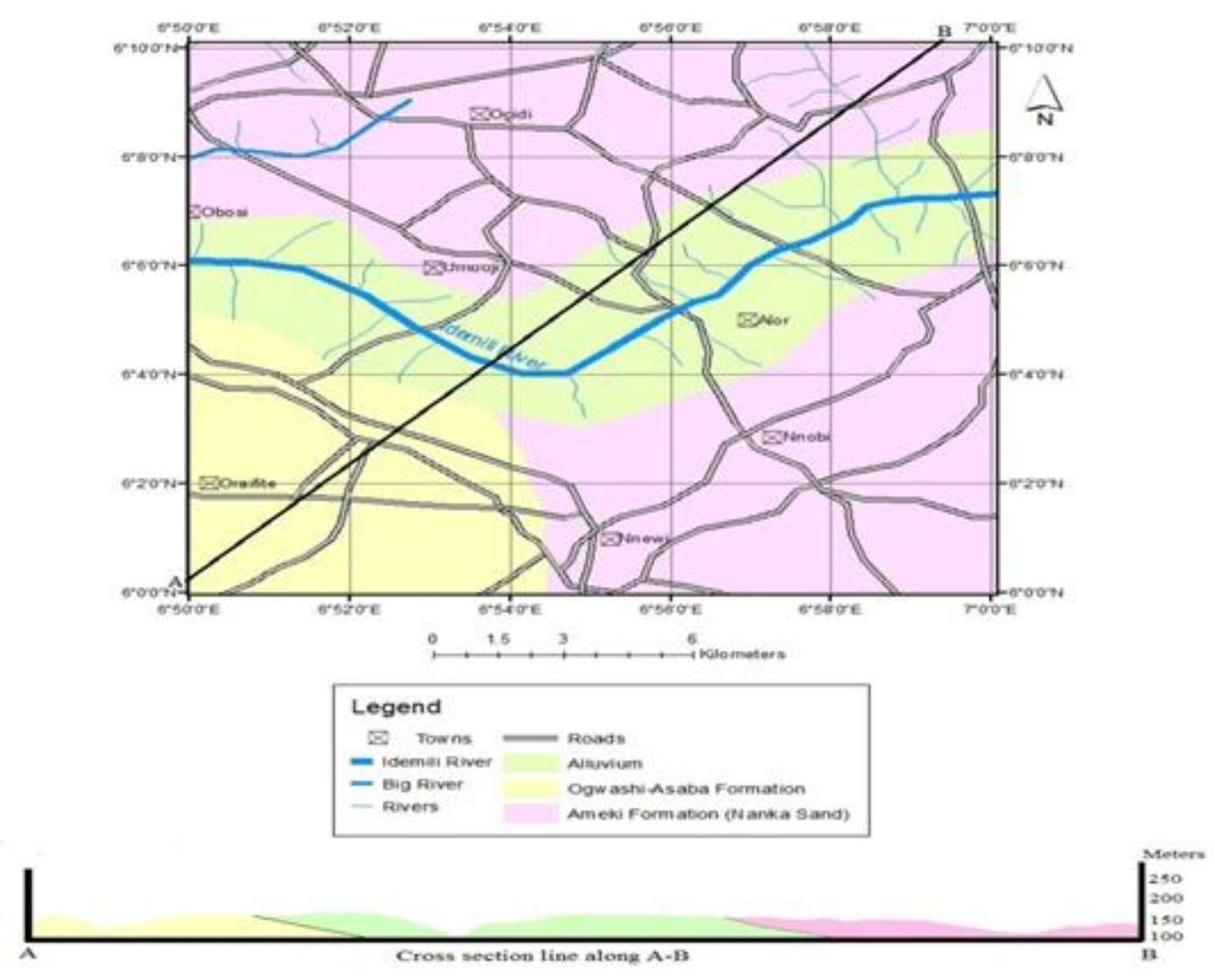

Fig: 1 Geologic map of the study area (Abor Sheet 300)

The study area displays highlands and lowlands with topographic heights ranging from $60 \mathrm{~m}$ to $180 \mathrm{~m}$ at Umuoji and $300 \mathrm{~m}$ to $320 \mathrm{~m}$ above sea level at Nnobi; the elevation of the land slopes generally to the west of the area. The rivers and streams that made up the drainage system in the study area comprised River Idemili, Mmiri John, Ngbor and Ezigbo. Hydraulic connectivity exists between the surface water systems and the groundwater systems. Through the phases of hydrogeologic cycle the groundwater system is recharged from infiltration of part of overland flow into the soil (Fetter, 2001; Heath, 1983).The drainage pattern of the Anambra basin is dentritic with individual streams flowing from sandy highlands to shaly lowlands. Meteorological, topographical and geological factors contribute to the amount of their flow and discharge. Fig. 2 and 3 are maps of Nigeria indicating study areas and topographic map of the study areas. 


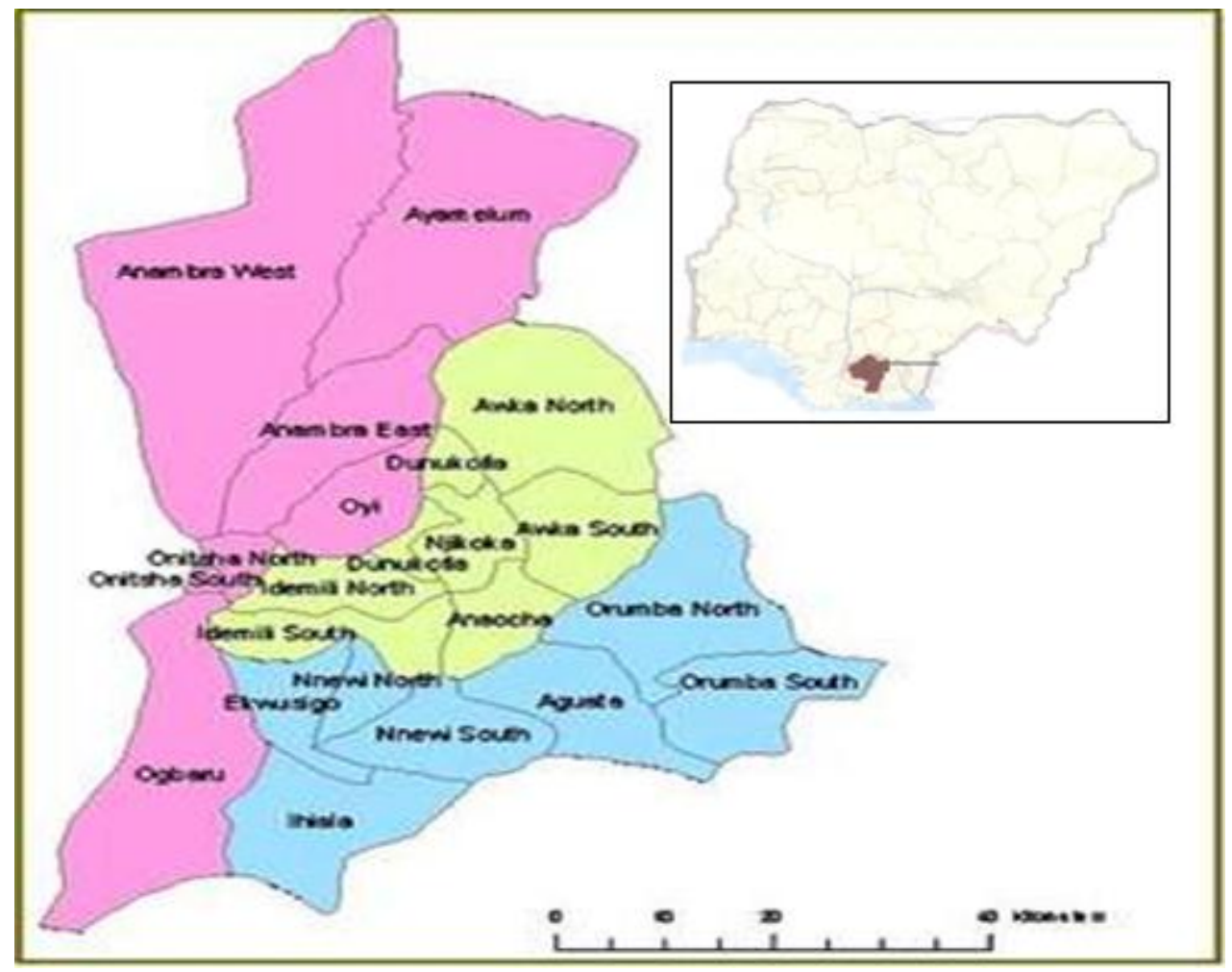

Fig. 2: Map of Anambra State Showing study area and inset is map of Nigeria (Ileoje, 1985)
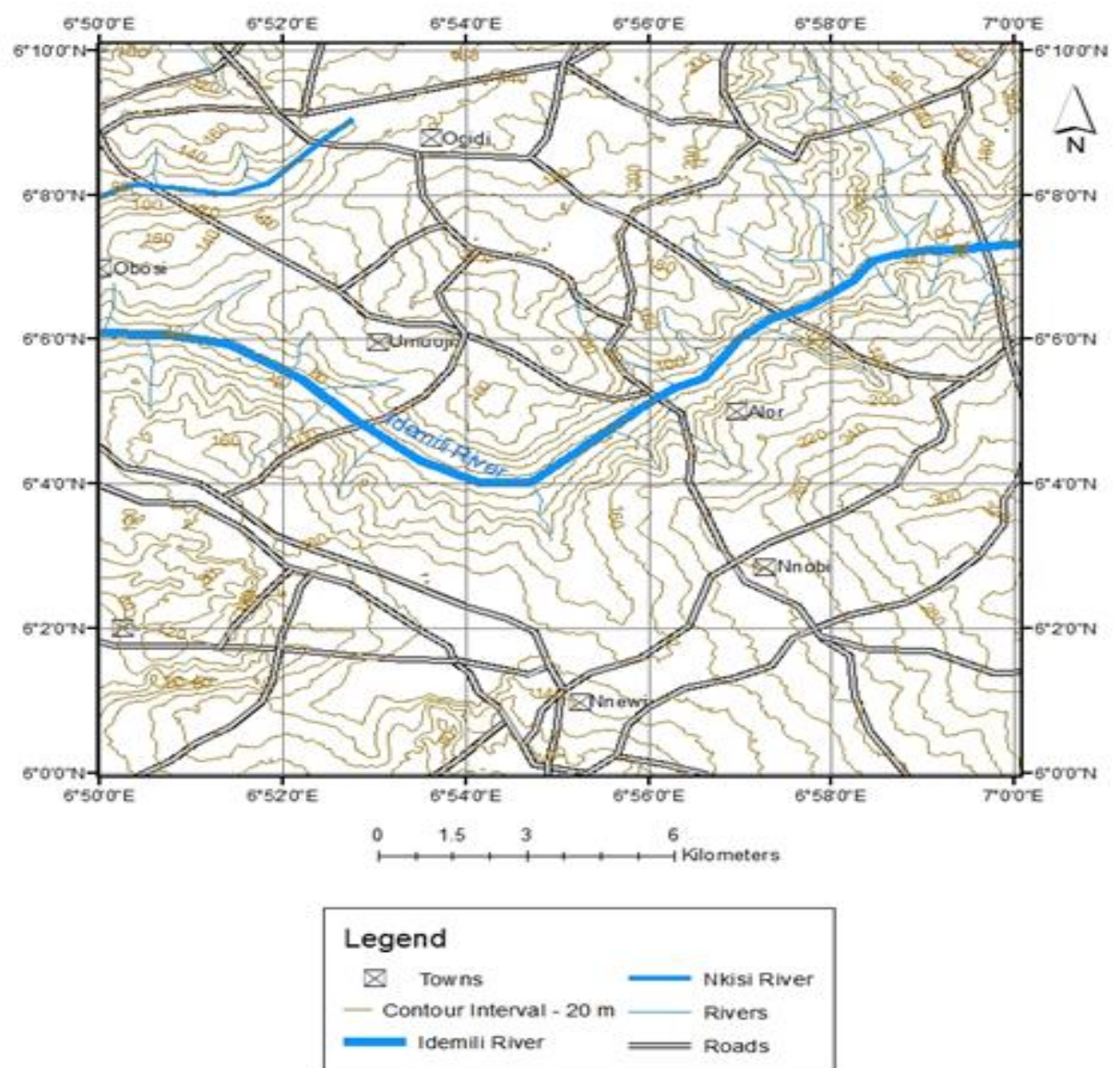

Fig. 3: Topographic Map of Study Area (Adopted from Abor, Sheet 300). 


\section{Climate and Vegetation}

The study area lies within the Equatorial Monsoon climatic belts of Nigeria typified by the rainy and dry seasons. Average rainfall for the area is $1650 \mathrm{~mm}$ to $2000 \mathrm{~mm}$ a year (NIMET, 2012; Inyang, 1975). The rainy season lasts for about eight months (March to October) and the dry season last for about four months (November to February) in the study area. Rainfall is not so heavy within the months of March and May while rainfall is heaviest between June and September. The driest period is between November and February.

According to National Oceanic and Atmospheric Administration NOAA (2007), the climate is comparatively congenial. Average maximum and minimum temperatures are $32^{\circ} \mathrm{C}$ and $23^{\circ} \mathrm{C}$ respectively. The relative humidity for the wet months is $60 \%$ to $71 \%$. Evaporation rates are low $1.4 \mathrm{~mm}$ in the rainy season to a maximum value of $6.0 \mathrm{~mm}$ in the dry months.

The study area lies within the Tropical Rainforest Vegetation belt (Fig. 4). The heavy rain forest in some places have given way to light rainforest as a result of man's encroachment on the environment. Tropical Rainforest vegetation is characterized by tall trees with canopy strata, thick undergrowth and shrubs. Oil palm trees dominate the landscape and other species of trees found in the area include iroko, mango, Mahogany and oil bean

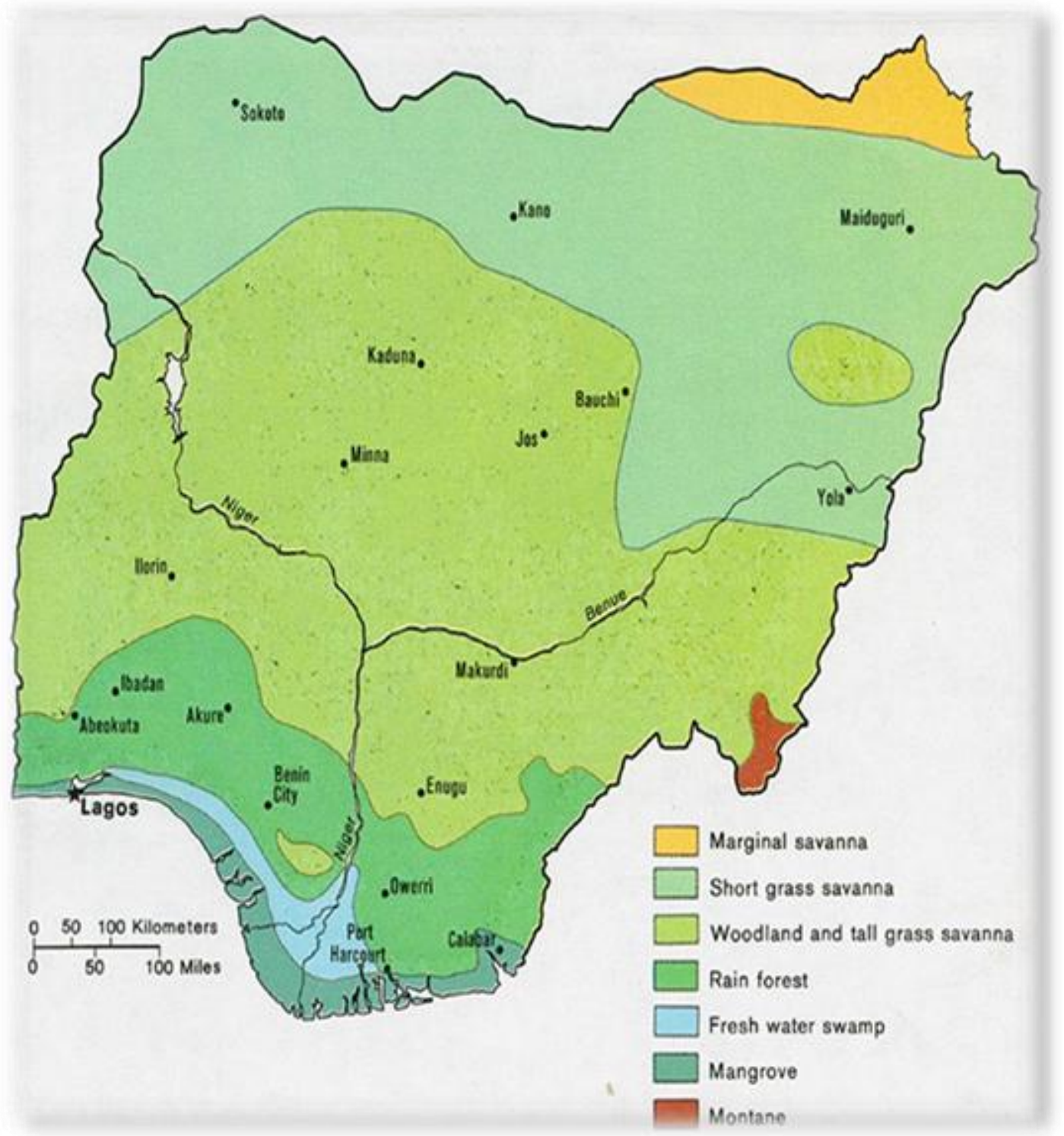

Fig. 4: Vegetation map of Nigeria showing the study area. (Macmillan, 2006). 


\section{MATERIALS AND METHODS}

Materials used for this study include note book, pencil, gum, leather bag, meter tape, water level sounders, Global Positioning System (GPS), board markers and topographic map (Abor Sheet 300). Road network, relief, drainage system were indicated on the base map produced from the topographic maps. Observations made during field work were recorded on the field notebook. Coordinates of the borehole sites were measured using the (GPS). Meteorological data for rainfall, temperature and evaporation were obtained from literature review of the area. Pumping test and recovery test was used to evaluate aquifer parameters of the area.

Data were collected during field studies and borehole drilling/pumping test operations, and from existing records, using standard procedures. Drill cuttings obtained during drilling were kept in wooden boxes. Water levels were obtained with the aid of water level depth sounders and the hydrogeological parameters used for the studies were obtained from borehole water samples, during which measurements were made and values obtained for depth of borehole, static water level, hydraulic head, dynamic water level, drawdown, borehole yield. The transmisivity, hydraulic conductivity and specific capacity were then computed from the raw data using relevant formulae.

\section{RESULTS AND ANALYSIS}

The results obtained for this study are presented in tables for the evaluated hydrogeologic (aquifer) parameters Pumping test results (Table 1), recovery test results (Table 2) and the draw down equilibrium graphs obtained from pumping test (Fig. 5 to 16) are also presented herewith.

\section{DISCUSSIONS}

At Akaboukwu, Uruagu, Nnewi underlain by the Ogwashi Asaba Formation, borehole drilled depth was 137 meters, static water level and dynamic water level recorded were 103 meters and 104.2 meters respectively and the drawdown was 1.21 meters. Computation made for hydraulic head, transmissivity, hydraulic conductivity, and specific yield are 29 meters, $65.62 \mathrm{~m}^{2} /$ day, $2.262 \mathrm{~m} / \mathrm{s}$ and $4.394 \mathrm{~m}^{2} / \mathrm{hr}$. respectively. The pumping test (Constant Discharge Test) and Recovery Test results showed that the groundwater resource potential is excellent, with high yield, high Trasmissivity, minimal drawdown and high specific capacity.
The depth of borehole in the Nanka Sands ranged from 134 meters in Mbanagu, Otolo Nnewi, through 186 meters at Nkolofia Awkaetiti to as high as 237 meters at Eziumuru, Nnobi. Static water level ranged from 40.84 meters at Ndimgbu, Otolo, Nnewi through 97.07 meters at Ochannachi, Nnobi, to 143 meters at Awkaetiti. Drawdown value ranged from 0.24 meters at umuezeani, Nnobi through 1.19 meters at Ndimgbu, Nnewi to 3.2 meters at Eziumuru, Nnobi. Borehole yield gave values of $62.53 \mathrm{~m}^{3} /$ day at Umunemelum, Nnobi through $119.96 \mathrm{~m}^{3} /$ day at Nkolofia, Awkaetiti, to $233.8 \mathrm{~m} 3 /$ day Ndimgbu, Nnewi. Computation made for hydraulic head ranged from 50 meters at Eziumuru, Nnobi through 61.22 meters at Awkaetiti to 94 meters at Ndimgbu, Nnewi. Transmissivity values ranged from $24.42 \mathrm{~m}^{2} /$ day at Umuobi, Nnobi through $61.70 \mathrm{~m}^{2} /$ day at Awkaetiti to $121.87 \mathrm{~m}^{2} /$ day at Ndimgbu, Nnewi. Hydraulic conductivity values ranged from $0.411 \mathrm{~m} / \mathrm{s}$ at Umuobi,Nnobi through $3.937 \mathrm{~m} / \mathrm{s}$ at Nkolofia, Awkaetiti to $4.479 \mathrm{~m} / \mathrm{s}$ at Umuhai, Nnobi. Specific capacity values ranged from $1.496 \mathrm{~m}^{2} / \mathrm{hr}$ at Eziumuru, Nnobi through $8.864 \mathrm{~m}^{2} / \mathrm{hr}$ at Umudim, Nnewi to $20.14 \mathrm{~m}^{2} / \mathrm{hr}$ at Awkaetiti. The recovery test showed that the time for the borehole to fully recover ranged from 3 minutes at Umudim Nnewi through 9 minutes at Umuhai, Nnobi to 15 minutes at Akaboukwu, Uruagu, Nnewi.

The results of the aquifer characteristics of the study area revealed that, both the Nanka Sand and Ogwashi Asaba Formation aquifers are prolific especially if the geophysical/drilling and completion works are scientifically executed.

\section{CONCLUSION}

The results of this study showed that the aquifers characteristics of the studied area are good to excellent which make them highly productive. Groundwater supply here receives ample infiltration from abundant rainfall. The humidity is high both in the rainy season and dry season with a moderate temperature. Drawdown is minimal and transmisivity high as shown in pumping test results, suggesting good porosity and permeability and the characteristic friability normally associated with the underlying geologic units. Boreholes exploit the aquifers from shallow depths at the valley courses and lowlands to very great depths in the upland areas. The recharge of the aquifer is high and are due to the high favorable climatic, topographic and geological conditions. Groundwater exploitation in the area is very promising thus ensuring sustainable water supply to the inhabitants of the area. 
Table 1: Hydrogeologic Data of Study Area.

\begin{tabular}{|c|c|c|c|c|c|c|c|c|c|c|c|c|c|c|}
\hline & $\stackrel{\tilde{\sigma}}{0}$ & 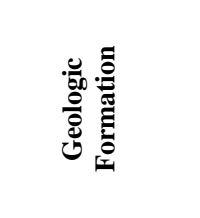 & $\begin{array}{l}z \\
z \\
0\end{array}$ & $\frac{1}{0}$ & 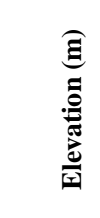 & 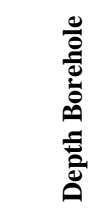 & 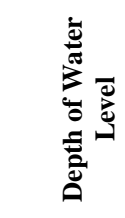 & 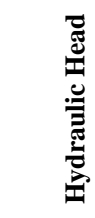 & 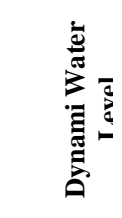 & 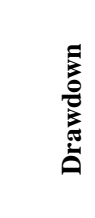 & 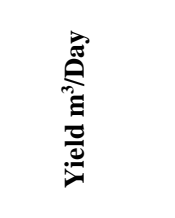 & 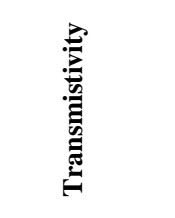 & 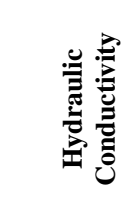 & 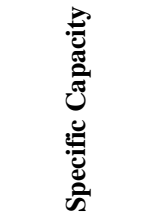 \\
\hline 1 & Ndimgbu Otolo Nnewi & Nanka Sand & $06^{0} 089.41$ & $06^{0} 947.96^{1}$ & 135 & 154 & 40.84 & 94.16 & 42.03 & 1.19 & $233.8 \mathrm{~m}^{3} / \mathrm{day}$ & $121.87 \mathrm{~m}^{2} / \mathrm{day}$ & $1.358 \mathrm{~m} / \mathrm{s}$ & $8.1866 \mathrm{~m}^{2} / \mathrm{hr}$ \\
\hline 2 & Akaboukwu Uruagu Nnewi & Ogwashi-Asaba & $06^{0} 038.30^{1}$ & $006^{0} 887.74$ & 132 & 137 & 103.0 & 29 & 104.21 & 1.21 & $127.6 \mathrm{~m}^{3} /$ day & $65.62 \mathrm{~m}^{2} /$ day & $2.262 \mathrm{~m} / \mathrm{s}$ & $4.394 \mathrm{~m}^{2} / \mathrm{hr}$ \\
\hline 3 & Mbanagu Otolo Nnewi & Nnaka Sand & $06^{0} 094.10^{1}$ & $006^{0} 943.14^{1}$ & 130 & 134 & 52.33 & 77.67 & 52.83 & 0.52 & $214.67 \mathrm{~m}^{3} /$ day & $112.49 \mathrm{~m}^{2} /$ day & $1.448 \mathrm{~m} / \mathrm{s}$ & $17.20 \mathrm{~m}^{2} / \mathrm{hr}$ \\
\hline 4 & Inyaba Umudim Nnewi & Nanka Sand & $06^{0} 030.10^{1}$ & $006^{0} 887.24^{1}$ & 141 & $180 \mathrm{~m}$ & 61.35 & 79.65 & 62.12 & 0.77 & $163.8 \mathrm{~m}^{3} / \mathrm{day}$ & $50.05 \mathrm{~m}^{2} /$ day & $0.628 \mathrm{~m} / \mathrm{s}$ & $8.864 \mathrm{~m}^{2} / \mathrm{hr}$ \\
\hline 5 & Umunemelum Nnobi & Nanka Sand & $06^{0} 03.927^{1}$ & $006^{0} 562.88^{1}$ & 181 & 235.3 & 121.23 & 59.77 & 122.62 & 1.42 & $62.53 \mathrm{~m}^{3} / \mathrm{day}$ & $25.64 \mathrm{~m}^{2} /$ day & $0.428 \mathrm{~m} / \mathrm{s}$ & $1.835 \mathrm{~m}^{2} / \mathrm{hr}$ \\
\hline 6 & Umuobi Nnobi & Nanka Sand & $06^{0} 03.449^{1}$ & $006^{0} 56.432^{1}$ & 202 & 241 & $142.7 \mathrm{~m}$ & 59.3 & 113.55 & 0.85 & $79.8 \mathrm{~m}^{3} /$ day & $24.42 \mathrm{~m}^{2} /$ day & $0.411 \mathrm{~m} / \mathrm{s}$ & $4.1 \mathrm{~m}^{2} / \mathrm{hr}$ \\
\hline 7 & Umuezeani Nnobi & Nanka Sand & $06^{0} 05.517^{1}$ & $006^{0} 92.284^{1}$ & 148 & 172 & 114.48 & 33.52 & 114.72 & 0.24 & $100.3 \mathrm{~m}^{3} /$ day & $61.04 \mathrm{~m}^{2} /$ day & $1.821 \mathrm{~m} / \mathrm{s}$ & $17.418 \mathrm{~m}^{2} / \mathrm{hr}$ \\
\hline 8 & Umuhai Nnobi & Nanka Sand & $06^{0} 05.080^{1}$ & $006^{0} 94.045^{1}$ & 145 & 164 & 118.8 & 26.2 & 120.24 & 1.44 & $140.74 \mathrm{~m}^{3} /$ day & $117.36 \mathrm{~m}^{2} /$ day & $4.479 \mathrm{~m} / \mathrm{s}$ & $4.0724 \mathrm{~m}^{2} / \mathrm{hr}$ \\
\hline 9 & Ochannachi Nnobi & Nanka Sand & $06^{0} 06.256^{1}$ & $006^{0} 92.729^{1}$ & 140 & 152 & 97.07 & 42.93 & 93.31 & 2.24 & $185 \mathrm{~m}^{3} /$ day & $72.28 \mathrm{~m}^{2} /$ day & $1.682 \mathrm{~m} / \mathrm{s}$ & $3.4417 \mathrm{~m}^{2} / \mathrm{hr}$ \\
\hline 10 & Awka-Etiti & Nanka Sand & $06^{0} 03.753^{1}$ & $006^{0} 96.071^{1}$ & $203^{1}$ & 233 & $143.78 \mathrm{~m}$ & 61.22 & 144.10 & 0.32 & $154.7 \mathrm{~m}^{3} /$ day & $61.70 \mathrm{~m}^{2} /$ day & $1.007 \mathrm{~m} / \mathrm{s}$ & $20.14 \mathrm{~m}^{2} / \mathrm{hr}$ \\
\hline 11 & Nkolotia Awka-Etiti & Nanka Sand & $06^{0} 03.263^{1}$ & $006^{0} 95.971^{1}$ & 170 & 186 & 139.96 & 30.04 & 140.89 & 0.93 & $119.96 \mathrm{~m}^{3} /$ day & $118.27 \mathrm{~m}^{2} /$ day & $3.937 \mathrm{~m} / \mathrm{s}$ & $5.374 \mathrm{~m}^{2} / \mathrm{hr}$ \\
\hline 12 & Eziumuru Nnobi & Nanka Sand & $06^{0} 04.459^{1}$ & $006^{0} 57.433^{1}$ & 175 & 237 & 125 & 50 & 128.2 & 3.2 & $114.9 \mathrm{~m}^{3} / \mathrm{day}$ & $42.12 \mathrm{~m}^{2} / \mathrm{day}$ & $0.842 \mathrm{~m} / \mathrm{s}$ & $1.4963 \mathrm{~m}^{2} / \mathrm{hr}$ \\
\hline
\end{tabular}


Table 2: Pumping and Recovery Test Result of Study Area.

\begin{tabular}{|c|c|c|c|c|c|c|c|c|c|}
\hline \multirow[b]{2}{*}{ 孞 } & \multicolumn{5}{|c|}{ PUMPING TEST } & \multicolumn{4}{|c|}{ RECOVERY TEST } \\
\hline & $\begin{array}{l}\text { TIME } \\
\text { PUMPING } \\
\text { STARTED } \\
\text { (MINS) }\end{array}$ & $\begin{array}{c}\text { TIME TO } \\
\text { DRAWNDOWN } \\
\text { EQUILIBRIUM } \\
\quad \text { (MINS) }\end{array}$ & $\begin{array}{c}\text { STATIC } \\
\text { WATER } \\
\text { LEVEL (M) }\end{array}$ & $\begin{array}{c}\text { WATER } \\
\text { LEVEL AT } \\
\text { EQUILIBRIUM } \\
\text { (M) }\end{array}$ & $\begin{array}{l}\text { DRAWNDOWN } \\
\text { EQUILIBRIUM } \\
(\mathrm{M})\end{array}$ & $\begin{array}{c}\text { TIME } \\
\text { PUMPING } \\
\text { STOPPED } \\
\text { (MINS) }\end{array}$ & $\begin{array}{l}\text { WATER LEVEL } \\
\text { WHEN PUMPING } \\
\text { STOPPED (M) }\end{array}$ & $\begin{array}{l}\text { INITIAL } \\
\text { WATER } \\
\text { LEVEL } \\
\text { (M) }\end{array}$ & $\begin{array}{l}\text { TIME TO } \\
\text { RECOVERY } \\
\text { (MINS) }\end{array}$ \\
\hline 1 & 0 & 25 & 40.84 & 42.03 & 1.19 & 0 & 42.03 & 40.84 & 12 \\
\hline 2 & 0 & 7 & 103.00 & 104.33 & 1.30 & 0 & 104.21 & 103.00 & 15 \\
\hline 3 & 0 & 60 & 53.33 & 52.85 & 0.52 & 0 & 52.33 & 52.85 & 6 \\
\hline 4 & 0 & 4 & 61.35 & 62.12 & 0.77 & 0 & 61.35 & 62.12 & 3 \\
\hline 5 & 0 & 5 & 121.23 & 122.65 & 1.42 & 0 & 121.23 & 122.65 & 6 \\
\hline 6 & 0 & 6 & 142.73 & 143.56 & 0.86 & 0 & 143.56 & 142.73 & 5 \\
\hline 7 & 0 & 8 & 114.48 & 114.72 & 0.24 & 0 & 114.48 & 114.72 & 4 \\
\hline 8 & 0 & 5 & 118.85 & 120.45 & 1.65 & 0 & 120.45 & 118.80 & 9 \\
\hline 9 & 0 & 30 & 97.07 & 99.31 & 2.24 & 0 & 99.31 & 97.07 & 7 \\
\hline 10 & 0 & 25 & 143.78 & 144.11 & 0.32 & 0 & 144.10 & 143.78 & 6 \\
\hline 11 & 0 & 60 & 139.96 & 140.89 & 0.93 & 0 & 140.89 & 139.96 & 6 \\
\hline 12 & 0 & 10 & 125.00 & 128.20 & 3.20 & 0 & 125.00 & 128.20 & 10 \\
\hline
\end{tabular}




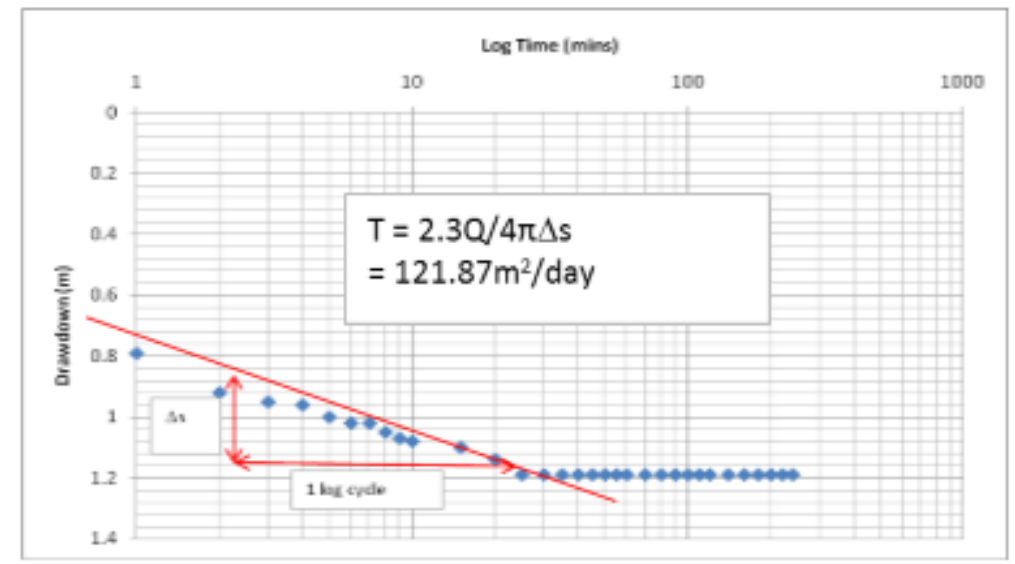

Fig. 5: Drawdown Graph of Location 1.

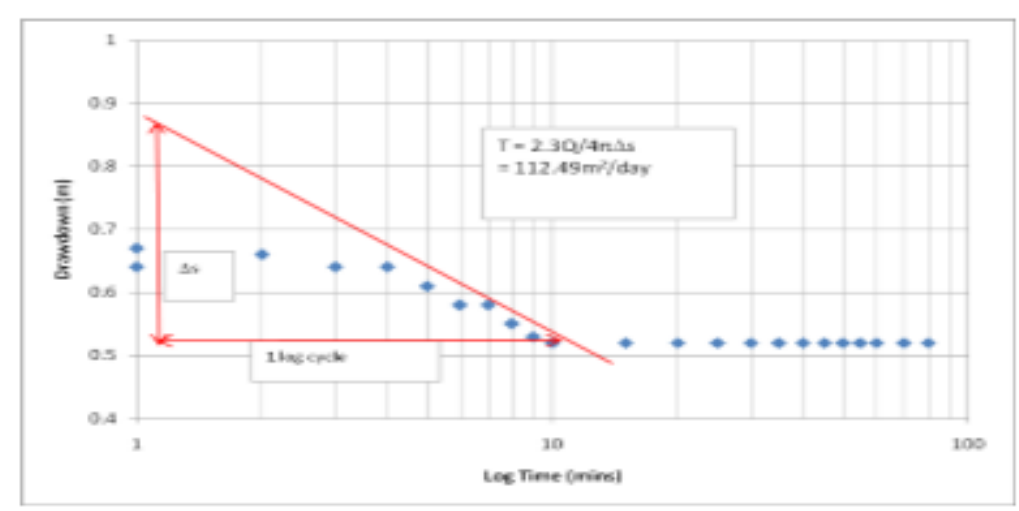

Fig. 7: Drawdown Graph of Location 3

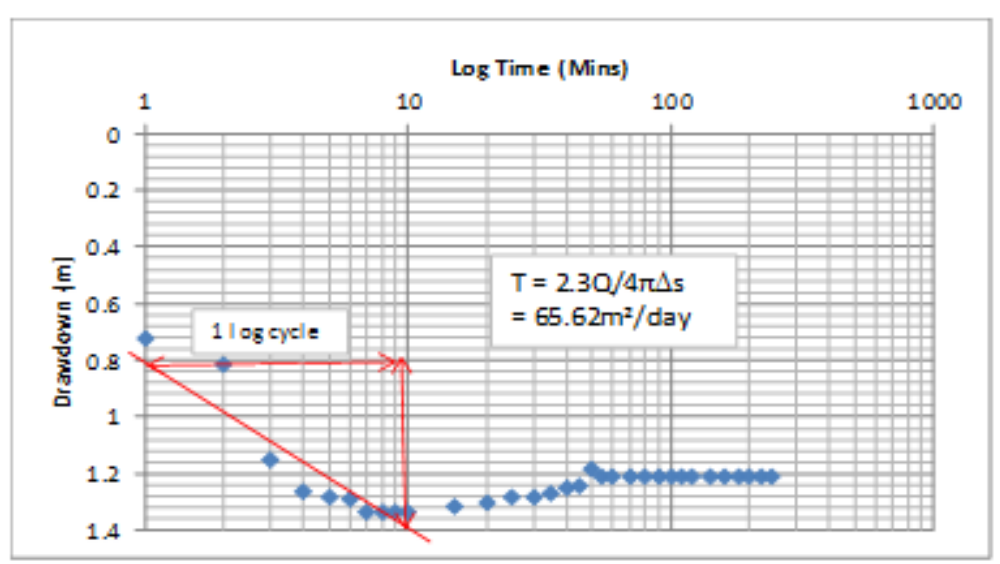

Fig. 6: Drawdown Graph of Location 2

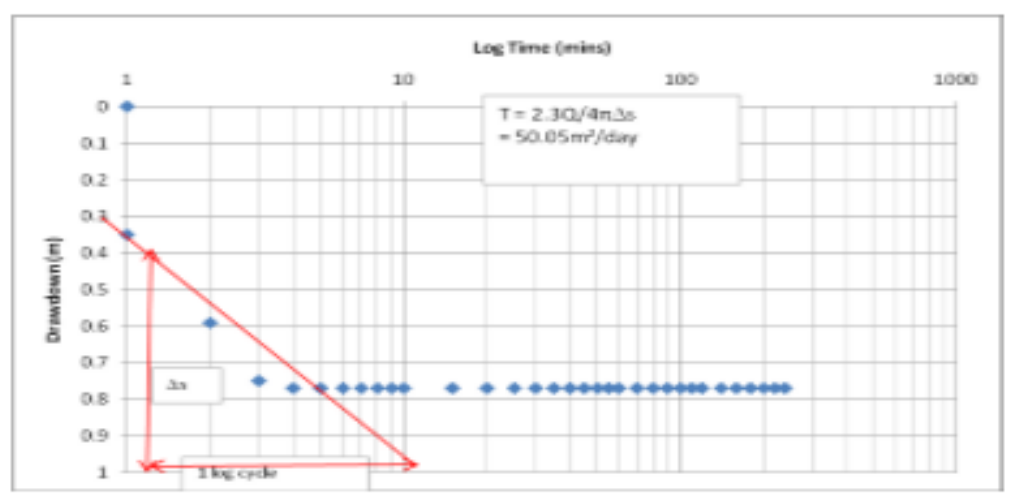

Fig. 8: Drawdown Graph of Location 4 


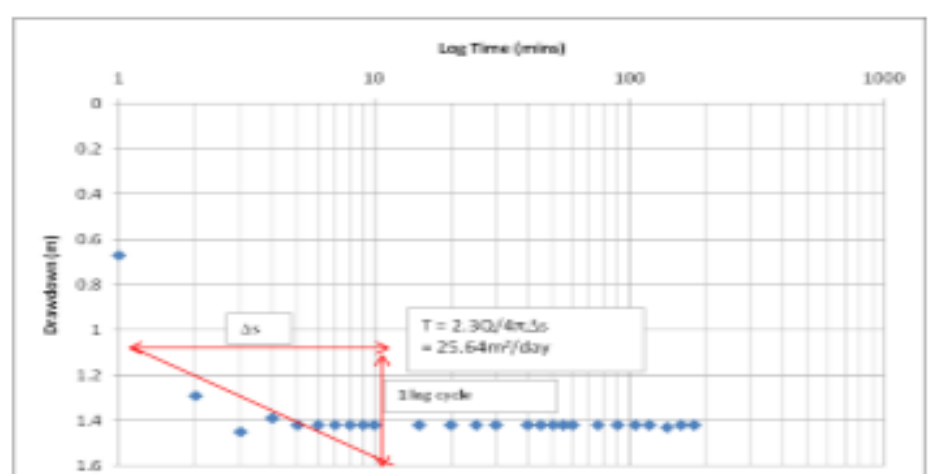

Fig. 9: Drawdown Graph of Location 5

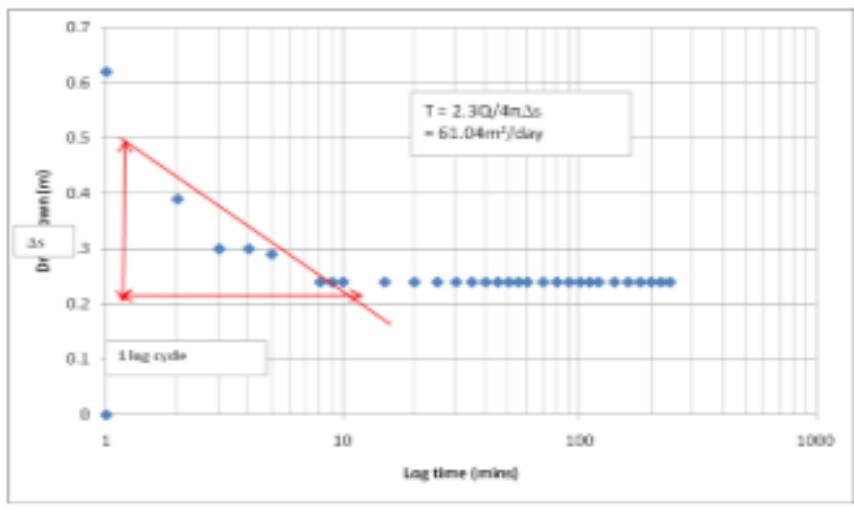

Fig. 11: Drawdown Graph of Location 7

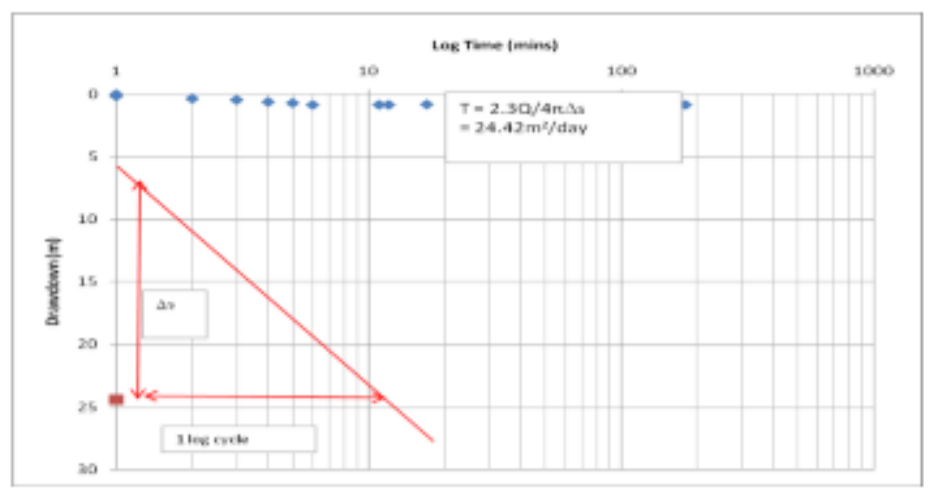

Fig. 10: Drawdown Graph of Location 6

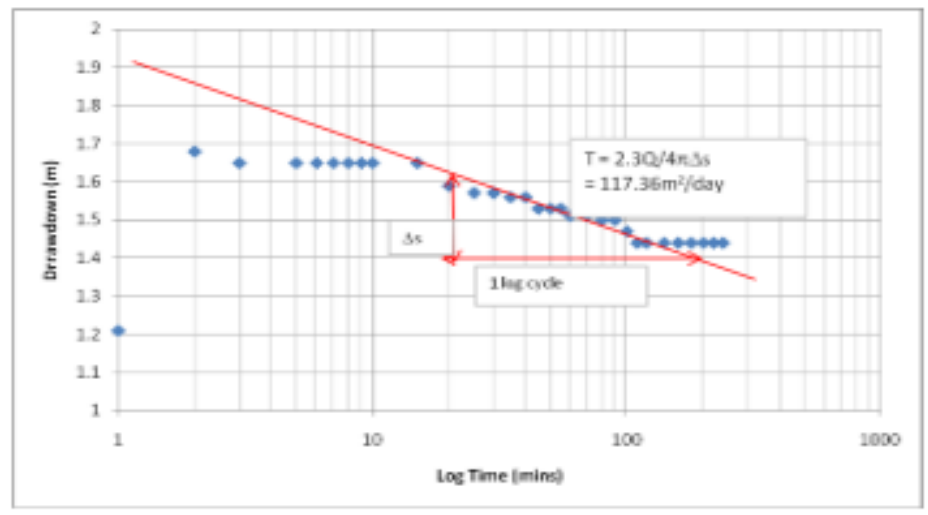

Fig. 12: Drawdown Graph of Location 8 


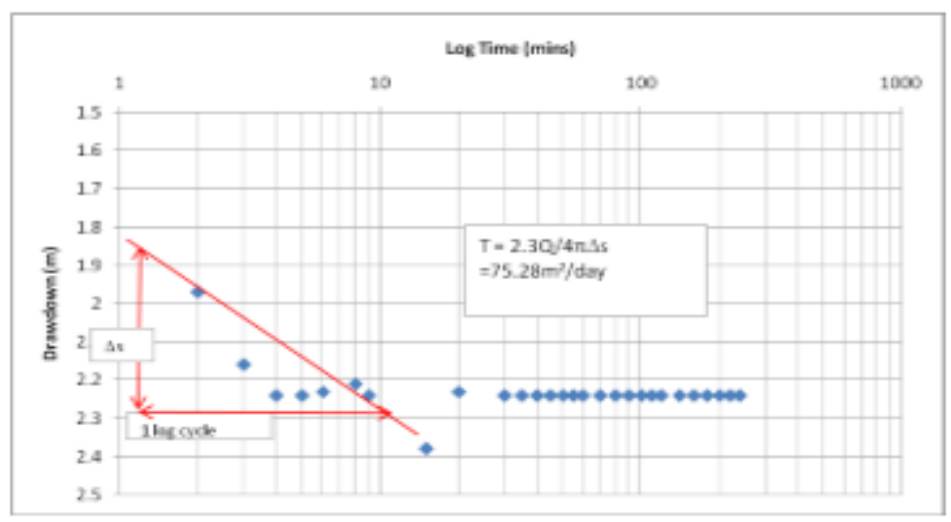

Fig. 13: Drawdown Graph of Location 9

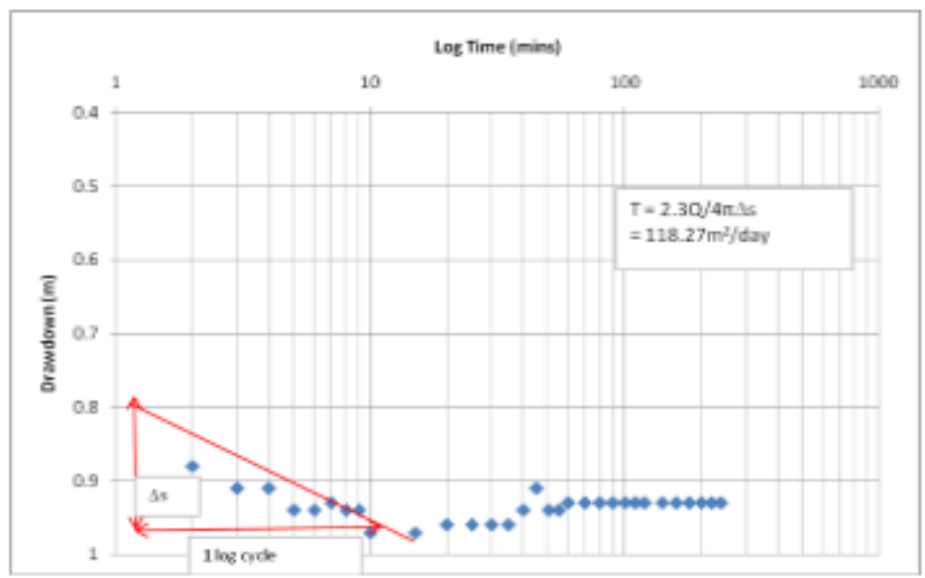

Fig. 15: Drawdown Graph of Location 11

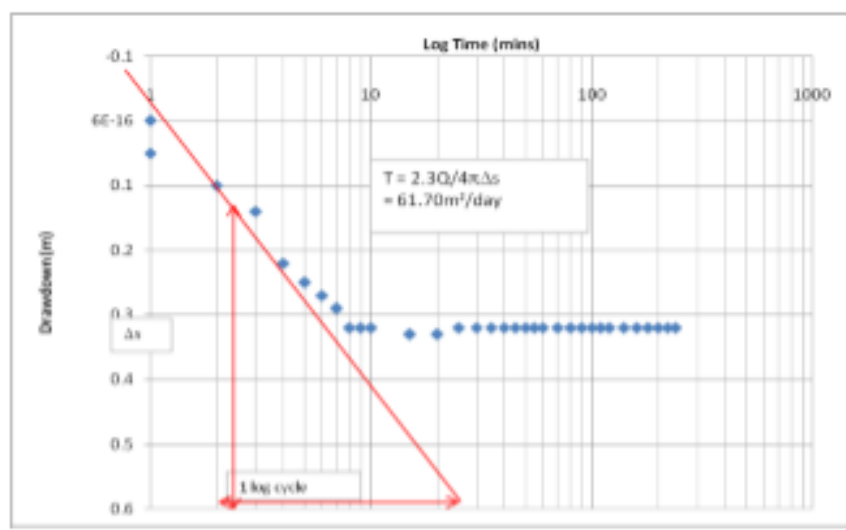

Fig. 14: Drawdown Graph of Location 10

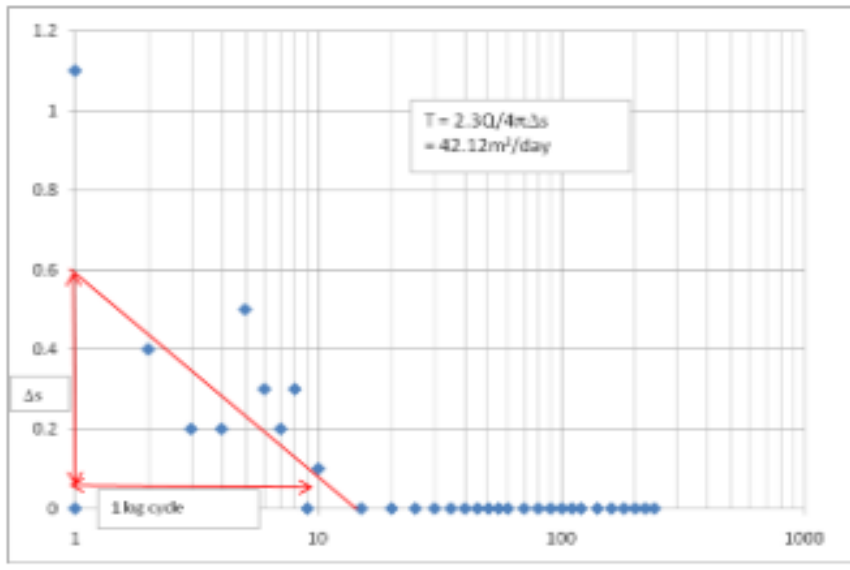

Fig. 16: Drawdown Graph of Location 12 


\section{REFERENCES}

Agagu, O. K. and Ekweozor, C. M (1982). Source-rock Characteristics of Senonian Shales in the Anambra Syncline, Nigeria J. mining Geol. 19 (1) pp. 132-140

Ajayi, M. O. (1987). The Philosophy and Politics of Rural Development in Nigeria. Journal of Nigeria Institute of Town Planning. Vol. VIIe/1x

Akaegbobi, I. M (2005). Sequence Stratigraphy and Predictive Hydrocarbon Source Potentials of the Campano-Maastrichtian Shale Outcropping at Enugu, Anambra Basin Nigeria. NAPE $23^{\text {rd }}$ Annual internal. Conf. book of abst. A40

Alley, W. M., Healy, R.W., Labaugh, J. W. \& Reilly, T. E. (2002). Flow and storage in groundwater system, Science, V.206.

Bain, A. D. N. (1924). The Nigeria Coalfield, Section 1, Enugu Area, Bull. Geol. Surv. Nigeria pp 1-81Tattam, C.M (1944) A Review of Nigeria Stratigraphy. Rep. Geol. Surv. Nigeria.

Cherry, J. A. (1999). Groundwater Occurrence and Contamination in Canada Aquatic Water Resources (M. Healy. Ed).

De Rooy, C., Kamfort, M., and Sambile, O. (1986). An Empirical Hydrogeological Model for Groundwater Prospecting. Nature and Resources, Vol. XXX 1. No.

Edington, G.M. and Mcheen, C.M.U. (1965) A Cancer rate survey in Ibadan, Western Nigeria. Bir. J. Cancer, Vol. 19 pp 471-481.

Egboka, B. C. E., (1998). Hydrogeological Provinces of Nigeria. Water quality Bull. 13 (4): 117-123.

Egboka, B. C. E., Nfor, B. N. \& Banlanjo, E. W. (2006). Water budget Analysis of Agulu Lake in Anambra State, Nigeria. J.App. Sci. Environ. Mgt. 10(3), pp 27-30.

Egboka, B.C.E, and Ezeonu, F. C (1990). Nitrate and Nitrite Pollution and Contamination in Parte of Eastern Nigeria. A case study of a developing economy. Journal of NAH. Vol. 2. No. 1

Egboka, B.C.E, and Onyebueke, F.O, (1990). Acute Hydrogeological Problems Vis-à-vis Planning and Management of a Developing Economy. A case study of Enugu Area, Nigeria. Journal of water resources of the NAH. Vol. 2 No. 1.

Egboka, B.C.E, Nwankwo, G. I, Orajaka, I. P and Ejiofor, A. O (1989). Principles and Problems of Environmental Pollution of Groundwater Resources with Case examples from developing countries. Journal of NAH. Vol. 2 NO.1.

Ezeigbo, H. I. (1987). Quality of Water Resources in Anambra State, Nigeria. Journal of Mining and Geology. No. 23, Vol. 1 and 2, pp 97-103

Ezeigbo, H. I. (1990). Facilities for Credible Hydrologic Studies in Nigeria. Journal of Water Resources of the NAH. Vol. 2. No. 1.

Ezeigbo, H. I., Ozoko, D. C. (1989). An Evaluation of the water Resources of Nsukka and Environs, Anambra State, Nigeria. Water Resources Journal of NAH. Vol. 1. No. 2. pp. 20-25

Ezenwa, S. O (1988). Hydrogeological Studies and Evaluation in Maiduguri Metropolis and Environs. An unpublished M.Sc. Thesis. University of Maiduguri, Nigeria.

Falconer, J. D. (1911). The Geology and Geography of Northern Nigeria. Macmillan London, 295, 1911. Universal Journal of Geoscience 2(3): 93-102.

Fetter, C.W. Jnr. (2001). Applied Hydrogeology, $4^{\text {th }}$ Edition. Pp. 583.

Heath, R. C. (1983). Basic Groundwater Hydrology, U. S Geological Survey water supply paper 2220. Pp 86.

Iloeje, N.P (1985). A New Geography of West Africa. Longman Nigeria Ltd, Ibadan. Pp. 203.

Inyang, P. E. B (1975). Climatic Conditions in Nigeria in Maps. Eastern States Ed. By Ofomata GEK Ethiope Publishers, Benin. Pp. 27-29.

Johnson, J. (1982). Manufacturing Area in Cities. "Urban Geography" An Introduction Analyses. Pergamm Press Ltd. Oxford pp 12-15

Kogbe, C. A., Calvez, L. E, Mehes, K., and Salemin, M. B (1976). Biostrtigraphy of Upper Cretaceous and Tertiary Sediments penetrated by Gbekebo "B" well, Niger Delta, Nigeria. In Geology of Nigeria (Ed) 253.259. Elis Publ. Co. Lagos.

Lindroff, D. E. (1979). Groundwater Pollution-a status report. Goundwater17 (1): 9-17

Macmillan Nigeria Secondary Atlas, (2006). Macmillan Publishers Ltd., Lagos, Nigeria. 136p.

Mekelvy, V. E., (2005). Beach Sediment of trout Lake. Winsconsin. Journal Sedimentary Pedology V. 10, Pp 65-67

Nfor, B. N. (2003). Sedimentary Facies and the Diagnostic characteristics for Campanian Eocene Anambra Basin; Unpublished Ph.D Thesis. Submitted to the Department of Geological Sciences, Nnamdi Azikiwe University, Awka. P.236.

Nfor, B. N., Olabaniyi, S. B, and Ogala, J. E. (2007). Extent and Distribution of Groundwater Resources in parts of Anambra State, Southeastern Nigeria. Journal of Appl. Sci. Environ. Manage. Vol. 11 (2), 215-221

Nwajide, C. S. (1979). A Lithostratigraphic Analysis of Nanka Sands, Southern Nigeria. Journal of Mineral Geology in Nigeria PP. 103-108

Nwajide, C. S. (2013). Geology of Nigeria's Sedimentary Basins. CSS Bookshops Ltd, Lagos Nigeria 565p.

Nwokolo, C. and Okonkwo, F. O. (1972). Aflatoxin load of Common Food in Savannah and Forest Regions of Nigeria. Trans. Royal Soc. Tron. Med. And Hyg., Vol 72

Ofodile, M. E. (1988). Water Resources Management and the Nigerian groundwater systems. Water Resources of NAH. (i) pp.62-74.

Ofodile, M. E. (2002). Groundwater Study and Development in Nigeria. Published by Mecon Geology and Engineering Services, Jos, Nigeria. Pp. 453.

Oformah, J. C., Ezeigbo, H. I. (1997). Hydrogeological Evaluation of the Anambra River Basin, Southeastern Nigeria. Water resources Journal of NAH. Vol. 8. Nos. 1 and 2 pp.18-26.

Ojiegbe, R. U, (1990). Rural Water Poolution and Fertilizer Application. Journal of Water Resources of NAH. Vol. 2. No. 1. 
Okoro, E. I., Egboka, B. C. E., Onwuemesi, A. G. (2010). Evaluation of the aquifer characteristics of Nanka Sands using hydrogeological method in combination with Vertical Electric Sounding (VES). Journal Appl. Sci. Environ. Mgt. Vol. 14

Okpoko, E. I, (1987). Environmental Implication of Water Pollution in Developing Economy a case study of Anambra State. Journal of Water Resources of the NAH, Vol. 2 No. 1.

Okpoko, E. I. (1986). The Water Resources of Awka town and Environs. Unpublished M.Sc. Thesis, Dept of Geology ASUTECH.

Okpoko, E. I. (1995). Improving Water Supply Services in the Rural Areas of Anambra State, Nigeria Individual Development Project, Administrative Staff College of Nigeria, Lagos. p.45.

Okpoko, E. I. (2017). Hydrogeologic Evaluation and Modelling of Aquifer Systems in Amichi-Amesi Area of Southeast Nigeria. Chukwuemeke Odimegwu Ojukwu University Journal of Phy. Sci. 1 (1). 113.

Onuoha, K. M. (1986). Basin Subsidence, Sediment Decompaction, and Burial History Modelling
Techniques; Applicability to the Anambra Basin. In: Nigeria Assoc. petroleum expl. Proc. 2 pp6-17

Onwumesi, A. G. (1990). Hydrogeophysical and Geotechnical Investigation of the Ajali Sandstone in Nsukka and Environs, with reference to Groundwater Resources and Gully erosion problems. Journal of the water resources of NAH. Vol. 2 No.1

Onyekuru, S. O, Nwankwo, G. I and Akaolisa, C. Z (2010) Chemical Characteristics of Groundwater Systems in Southern Anambra Basin, Nigeria. Journal of Appli. Sci. Research, (12)

Oyenuga, Y. A. (1968). Nigerian Foods and Feed Stuff. Ibadan University Press. Ibadan, Nigeria.

Reyment, R. A. (1965). Aspect of Geology of Nigeria, Ibadan University Press Ibadan. pp.145.

Salff, S. (1992) Canada Sets in Sight of Reduction. Modern Power System International.

Schwartz, F. W. \& Zhang, H. (2003). Fundamentals of groundwater. John Wiley and Sons. N.Y. 583p.

Short, K. C. and Stauble, A. J. (1967). Outline Geology of the Niger Delta. AAPG Bulletin. No.31: 761-779.

\section{$\underline{\text { How to cite this article }}$}

Ejiagwa, O. N., Nfor, B. N., Okpoko, E. I. and Anene, C.Z. (2018). An Evaluation of Aquifer Characteristics of the Idemili River Catchment Area of Southeast, Nigeria. Tropical Journal of Applied Natural Sciences, 2(2): 107-118. Doi: https://doi.org/10.25240/TJANS.2018.2.2.14. 